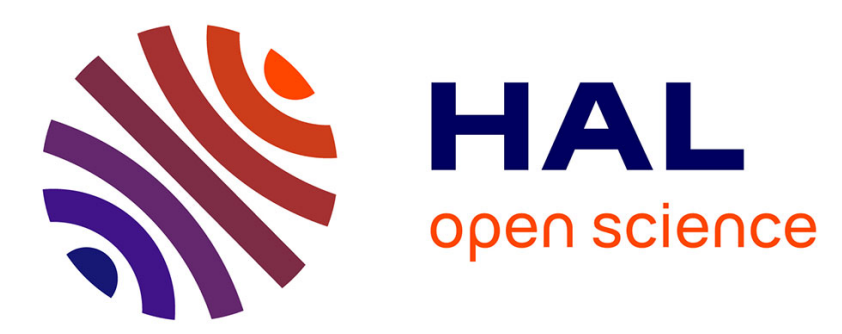

\title{
Control of sludge height in a secondary settler using fuzzy algorithms
}

Adama Traoré, Stéphane Grieu, Frédérik Thiéry, Monique Polit, Jesús

Colprim

\section{- To cite this version:}

Adama Traoré, Stéphane Grieu, Frédérik Thiéry, Monique Polit, Jesús Colprim. Control of sludge height in a secondary settler using fuzzy algorithms. Computers \& Chemical Engineering, 2006, 30 (8), pp.1235-1242. 10.1016/j.compchemeng.2006.02.020 . hal-01273203

\section{HAL Id: hal-01273203 \\ https://hal-univ-perp.archives-ouvertes.fr/hal-01273203}

Submitted on 12 Feb 2016

HAL is a multi-disciplinary open access archive for the deposit and dissemination of scientific research documents, whether they are published or not. The documents may come from teaching and research institutions in France or abroad, or from public or private research centers.
L'archive ouverte pluridisciplinaire HAL, est destinée au dépôt et à la diffusion de documents scientifiques de niveau recherche, publiés ou non, émanant des établissements d'enseignement et de recherche français ou étrangers, des laboratoires publics ou privés. 


\title{
Control of sludge height in a secondary settler using fuzzy algorithms
}

\author{
A. Traoré*, S. Grieu*, F. Thiery*, M. Polit ${ }^{*, 1}$, J. Colprim** \\ * Laboratoire de Physique Appliquée et d'Automatique, Université de \\ Perpignan, 52 Avenue Paul Alduy, 66860 Perpignan, France. \\ ** Chemical and Environmental Engineering Laboratory, University of Girona \\ (LEQUIA-UdG), Campus Montilivi s/n E-17071 Girona, Catalonia, Spain.
}

\begin{abstract}
During the last years, the efficiency of pollution removal and sludge treatment processes are major concerns because of the more restrictive legislation related to nutrient discharge. A key point in the field of activated sludge wastewater treatment plants (WWTPs) is the secondary settler efficiency. This paper presents a benchmark study to control, using fuzzy algorithms, the sludge height in a secondary settler. The presented control strategy is based on simple on-line data (influent and recycle flows) and daily analitycal values of the Sludge Volume Index (SVI) allowing the fuzzy algorithm to reduce sludge height variations and thus to increase the settling process efficiency. The developed controller has been applied to the Cassà de la Selva activated sludge WWTP (Spain).
\end{abstract}

Keywords : Pollution removal process monitoring and control, Wastewater treatment plant, Secondary settler efficiency, Sludge height, Fuzzy logic.

\section{Introduction}

Among the industrial techniques used in the field of wastewater treatment, the biological way is indeed the most popular. Particularly, processes based on activated sludge technology (DaMotta et al., 2000) offer a very good solution for pollution removal in urban wastewater. Considering the complexity of the physical, chemical and biological phenomena involved into treatment units, process performances highly depend on environmental and operational conditions. If those conditions are not optimised or controled, abnormal deviations can appear and affect effluent quality. To avoid such situations, control and supervision methods are required to follow processes state and evolution. Nevertheless, because of the processes high complexity, on-line methodologies based on state measurements are still under development.

The first works on bioprocess control and monitoring were based on classical techniques. However, because of the systems non-linear and time-varying characteristic, applications of such strategies are limited around a defined set point. Due to this situation, a considerable attention is focused on artificial intelligence modern techniques. The lack of reliable on-line sensors supported the development of control methods based on fuzzy algorithms. In fact, fuzzy reasoning techniques are means for human-friendly computerised devices (Dubois et al., 1996). They provide a symbolic generalization of numerical data using fuzzy sets and allow a linguistic interpretability (Zadeh, 1996). One of the critical point affecting classical biological reactors is the secondary settler efficiency, where the mixed liquor from the biological reator is settled in order to obtain a clarified effluent prior to final discharge. Parameters involved in the settling phase and highly affecting the pollution removal process efficiency have been studied for a long time (Ekama et al., 1997). In some cases, the microorganisms concentration or nature can lead to a deficient settling or to a bulking phenomenon (Jenkins et al., 
2003). Thus, a permanent follow-up of some physical and biological parameters influencing the sludge quality is needed. In general, this requires a control action to keep the process operating conditions in their optimum range, i.e. an operation taking into account the dynamical evolution of the system. Actions to apply could vary from precise chlorination to manual removal of superficial foam, including some adjustments related to recycling flows (Wanner, 1994).

In this paper, the ability of fuzzy logic to integrate human knowledge is exploited in order to maintain the secondary settler under stable conditions. The proposed approach is based on a strategy allowing to control the settled solids height (i.e. sludge blanket) in the secondary settler using simple combinations of on-line and off-line data. In spite of the existence of some commercial sensors able to on-line measure the sludge blanket, their implementation in real WWTPs is still occasional. The sludge blanket control is not widely spread. Thus, this paper presents an easy methodology to control the sludge blanket by measuring simple on-line (influent flow) and off-line (a daily measured Sludge Volumetric Index, SVI) parameters and manipulating the RAS recycle flow. The controller is based on simple fuzzy algorithms and has been developed using the COST simulation benchmark (Copp, 2001). It has been applied to the Cassà de la Selva activated sludge wastewater treatment plant (Girona, N.E. Spain).

\section{Methodology}

\subsection{The COST simulation benchmark}

Bioprocesses are based on bacteria activity and characterized by a slow evolution compared to chemical reactions. Nevertheless they are very easy to destabilize. For this reason, using modern modelling and simulation techniques is essential to develop powerful control strategies (Gomes \&
Menawat, 2000) before any application on a real plant. In fact, a serie of simulations is particularly useful when a lot of experiments are needed, because it allows a rapid reproduction of the cells behaviour (a few minutes, instead of many days or months), at low cost (just the computer electric consumption) and without any risk. Virtual experiments are generally used, in a primary step, to determine optimal conditions, for parameter adjusting or soft sensors validation. Among the simulation tools currently used for bioprocesses, GPS-X ${ }^{\circledR}$ is known as one of the best modular softwares, including a dynamic and friendly graphical user interface. This software allows the evaluation of control strategies on 40 types of processes and offers the possibility of real time communication with MATLAB ${ }^{\circledR}$ and its fuzzy logic toolbox.

The considered virtual process for this study is the COST 624 Simulation Benchmark (Copp, 2001), highly accepted by the international community. It concerns a block of models and synthetic data characteristics of an activated sludge process used to eliminate the organic matter and nitrogen from the domestic effluents. The simulation benchmark plant is composed of five reactors in series with a 10-layer secondary settling tank. Figure 1 shows a schematic representation of the layout. The total biological volume is $5999 \mathrm{~m}^{3}$ $\left(1000 \mathrm{~m}^{3}\right.$ for tanks 1 and $2,1333 \mathrm{~m}^{3}$ for tanks 3, 4 and 5). Tanks 1 and 2 are unaerated but fully mixed when tanks 3 , 4 and 5 are aerated using a maximum $K_{L} a$ (oxygen transfer coefficient) of 10 $\mathrm{hr}^{-1}$ and a dissolved oxygen saturation of $8 \mathrm{gO}_{2} \cdot \mathrm{m}^{-3}$.

The biological reactors are parameterized using the IAWQ ${ }^{2}$ Activated Sludge Model 1 (ASM1) (Henze et al., 1987). The settling model used is the doubleexponential settling velocity function of Takacs (Takacs et al., 1991). It is based on the solids flux concept and is applicable to both hindered and flocculent settling conditions. 


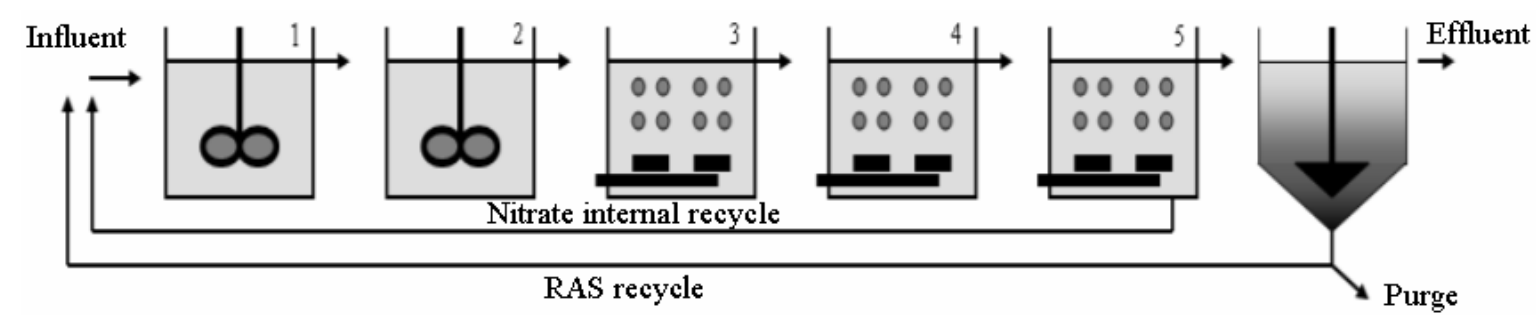

Fig.1. Schematic representation of the simulation benchmark configuration showing tanks

$1 \& 2$ mixed and unaerated, tanks $3,4 \& 5$ aerated, a settler and two internal recycles.

The settler is a non-reactive one with a total volume of $6000 \mathrm{~m}^{3}$ (area of $1500 \mathrm{~m}^{3}$ and depth of $4 \mathrm{~m}$ ) subdivided into ten layers and taking into account the vertical transfers between layers.

The layout presents two internal recycles $:$ the nitrate internal recycle from the $5^{\text {th }}$ to the $1^{\text {st }}$ tank at a default flow rate of $55338 \mathrm{~m} 3 / \mathrm{d}$ and the RAS recycle from the underflow of the secondary settler to the front end of the plant at a default flow rate of $18446 \mathrm{~m} 3 / \mathrm{d}$ (as there is no biological reaction in the settler, the oxygen concentration in the recycle is the same as in the $5^{\text {th }}$ tank reactor).

It has already been stated that the disturbances used to test a particular control strategy play a critical evaluation role. Because of the multifaceted nature of activated sludge, a particular control strategy may react well to a disturbance and not well to another. Thus, to carry out a complete and unbiased evaluation, it is necessary to define a series of disturbances and to subject each control strategy to all the disturbances. Three influent disturbances, representative of different weather conditions, have been defined. Each scenario contains 28 days of influent data with intervals of 15 minutes.

These scenarios are representative of three disturbances : dry weather, a storm event and a rain event. The dry weather scenario depicts what is considered to be normal diurnal variations in flow and COD load. The storm event scenario is a variation of the dry weather scenario, incorporating two storm events. The first storm event is of high intensity and short duration and is expected to flush the sewer of particulate material. The second storm event causes only a modest increase in COD load. The rain event scenario is characterized by a long rain event. The influent flow does not reach the level attained during the storm events, but the increased flow is sustained for a much longer period. There is no increase in COD load during this event (Vanhooren \& Nguyen, 1996). The rain is a frequent disturbance having an important impact on the WWTP operation, so we used the rain scenario in this work.

\subsection{Control architecture}

In biological wastewater treatment plants, the secondary settler is used for the sludge/effluent separation at the end of the treatment process. The water is then set on its way towards the end of the process and sludge settles at the bottom of the settler. For certain reasons (lack of oxygen, presence of greases, a too old sludge, excessive pollution rate), an increase of bacteria concentration can often be observed. This phenomenon is due to a fast reproduction and a growth of bacteria. It can produce, in some cases, sludge losses or process failures and has an impact on the sludge settling process efficiency. Sludge remaining at the surface is thus poured in the nature, inducing the non respect of increasingly constraining standards for rejects.

The objective of the present work is to develop an on-line control action with the aim of minimizing the variations of the sludge height in the secondary settler of a WWTP. Because of the difficulties of real time measuring the sludge height, the suspended solids concentration (MESS) at the middle of the settler $\left(5^{\text {th }}\right.$ 
layer) was used as the reference point to control. The suspended solids are mixed with bacteria to form the sludge. The proposed control strategy uses the influent flow (Qin) and the sludge volume index (SVI), a daily parameter characterizing the sludge quality, to estimate sluge recycle and removal flows, in order to minimize variations of the suspended solids concentration in the settler. The majority of sludge withdrawn from the settler is reinjected in the biological reactor (underflow rate Qr). In order to keep the reactor suspended solids under a desirable level, or because of nutrient removal objectives, a removal flow (Qp) is used. To improve the process qualitative knowledge, three simulations (Fig.2) were carried out, in order to evaluate the influence of the influent flow (Qin) and SVI on the suspended solid concentration in the settler during 20 days of normal situation. Thus, for default values of $\mathrm{Qr}$ $\left(18446 \mathrm{~m}^{3} / \mathrm{d}\right)$, Qp $\left(380 \mathrm{~m}^{3} / \mathrm{d}\right)$ and SVI $(150 \mathrm{ml} / \mathrm{g})$, suspended solids and influent flow are well correlated (Fig.2 (a)). For the two following simulations (Fig.2 (b) and Fig.2 (c)), different variations of SVI ranging between 20 and $220 \mathrm{ml} / \mathrm{g}$ cause an additive effect on the suspended solids concentration.

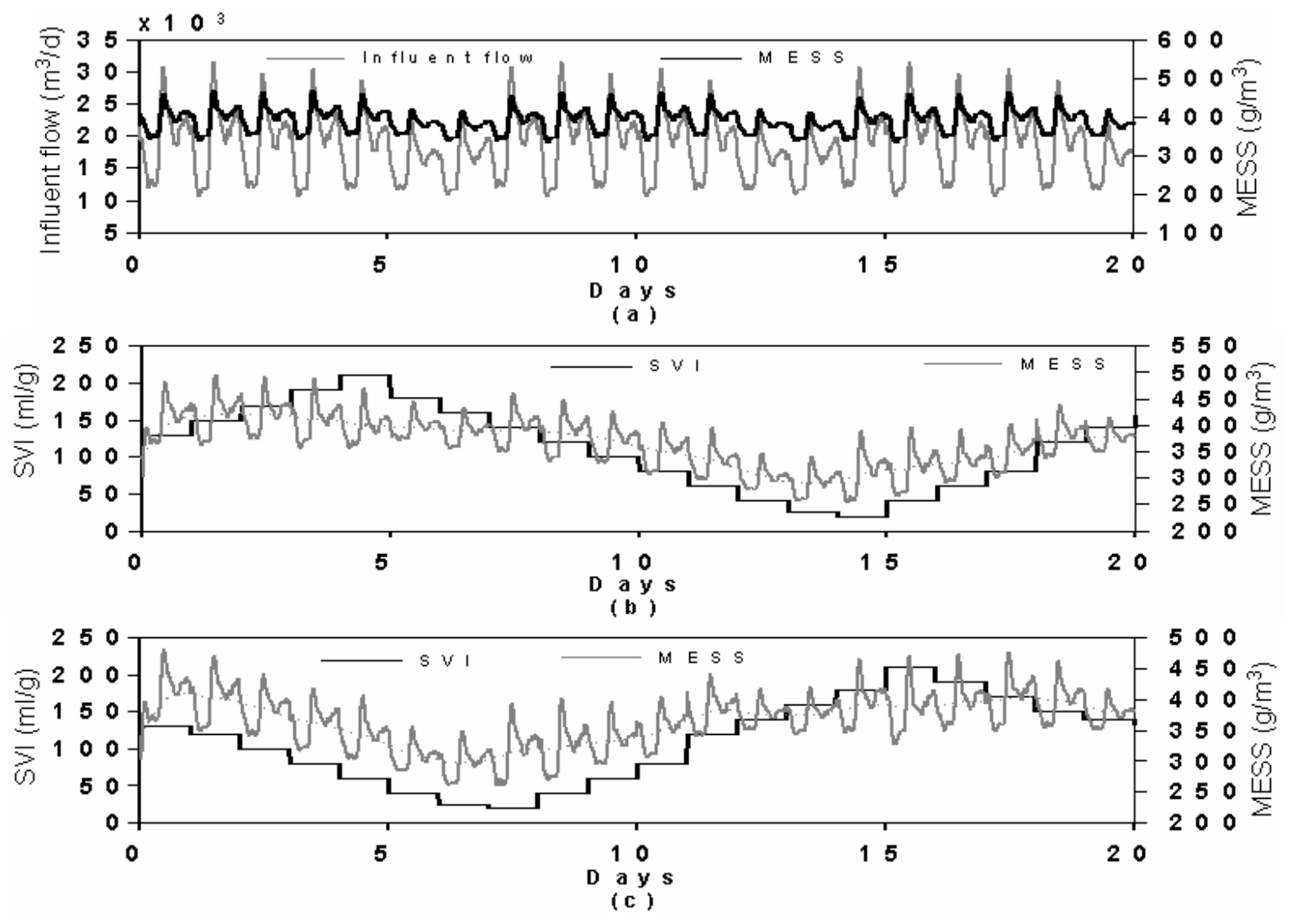

Fig.2. Influence of the different variables used as controller inputs on suspended solids.

(a) Influent flow, (b) SVI - First variations (c) SVI - Second variations.

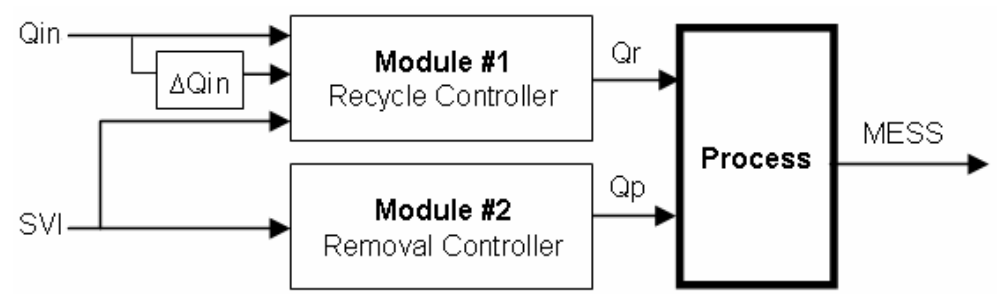

Fig.3. On-line controller architecture with Module \#1 (Recycle controller) and Module \#2 (Removal controller). 
The control strategy is based on the dissociation of the two influences mentioned before, by developing a controller with two modules. As shown on figure 3, the first module estimates Qr from measurements of Qin, its variation $\Delta$ Qin and SVI. $\Delta$ Qin is defined as : $\Delta \mathrm{Qin}(\mathrm{t})=\operatorname{Qin}(\mathrm{t})-\mathrm{Qin}(\mathrm{t}-\Delta \mathrm{T})$, where $\Delta \mathrm{T}=$ 45 minutes. The second module uses only SVI to estimate the removal flow Qp (purge).

In Module \#1, the first input (Qin) and the output (Qr) are both subdivided into
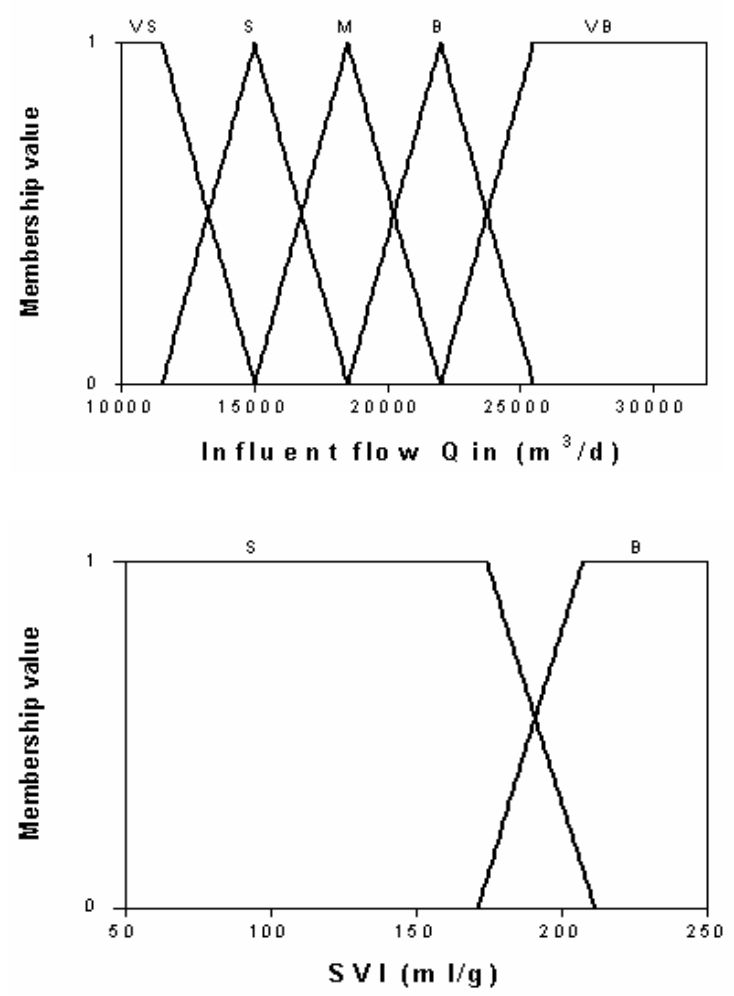

five identical fuzzy sets : Very Small (VS), Small (S), Mean (M), Big (B) and Very Big (VB). The second input ( $\Delta$ Qin) is subdivided into three fuzzy sets : Negative (N), Zero (Z) and Positive (P), whereas the SVI is divided into only two sets : Small (S) and Big (B).

Module \#2 is simpler, with three fuzzy sets (Small, Mean and Big) for both SVI and Qp. Figures 4 and 5 presents the different fuzzy sets for those two modules. The rules bases are assigned in tables 1 and 2.
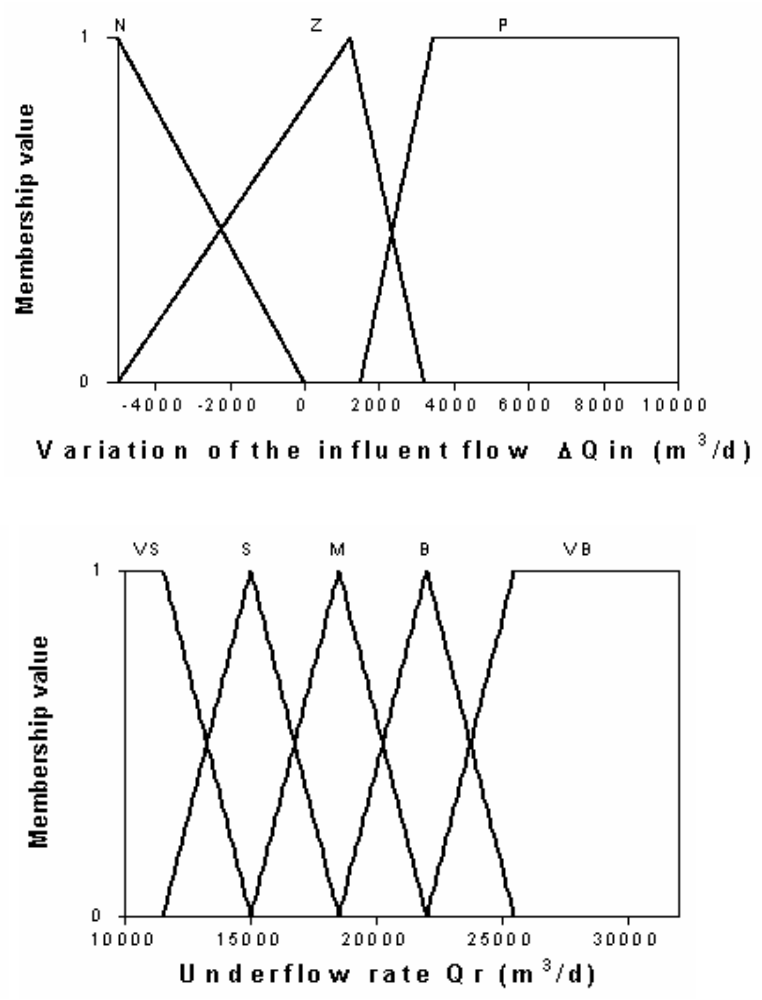

Fig.4. Fuzzy sets of the differents parameters (Influent flow Qin, Variation of the influent flow $\Delta$ Qin, SVI and Underflow rate Qr) used for Qr estimation (Module \#1).
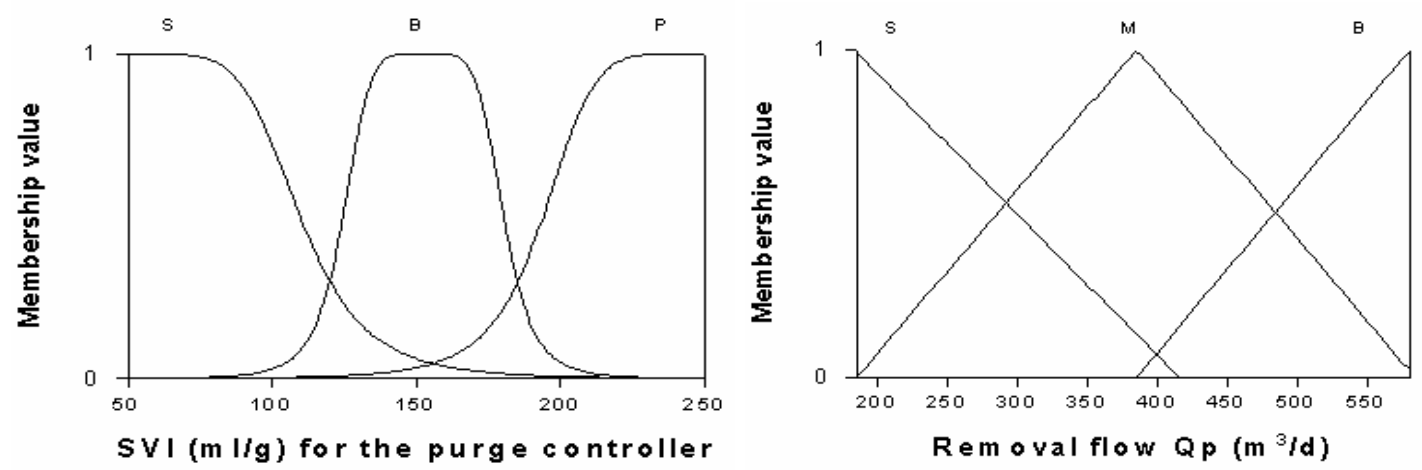

Fig.5. Fuzzy sets of the differents parameters (SVI and Removal flow Qp) used for Qp estimation (Module \#2). 
Tab.1. Rules bases used for the estimation of parameter Qr (Module \#1).

\begin{tabular}{|c|c|c|c|c|c|c|}
\hline \multirow{2}{*}{ Qr (SVI is $S)$} & \multicolumn{5}{|c|}{ Qin } \\
\cline { 3 - 7 } & VS & $S$ & $M$ & $B$ & $V B$ \\
\hline \multirow{4}{*}{ Qin } & $S$ & $V B$ & $M$ & $M$ & $M$ & $V S$ \\
\cline { 2 - 7 } & $M$ & $B$ & $B$ & $M$ & $S$ & $S$ \\
\cline { 2 - 7 } & $B$ & $V B$ & $M$ & $M$ & $S$ & $V S$ \\
\hline
\end{tabular}

\begin{tabular}{|c|c|c|c|c|c|c|}
\hline \multirow{2}{*}{ Qr (SVI is B) } & \multicolumn{5}{|c|}{ Qin } \\
\cline { 2 - 7 } & $\boldsymbol{V S}$ & $\boldsymbol{S}$ & $\boldsymbol{M}$ & $\boldsymbol{B}$ & $\boldsymbol{V} \boldsymbol{B}$ \\
\hline \multirow{3}{*}{$\Delta$ Qin } & $\boldsymbol{S}$ & $V B$ & $B$ & $B$ & $B$ & $S$ \\
\cline { 2 - 7 } & $\boldsymbol{M}$ & $V B$ & $V B$ & $B$ & $M$ & $M$ \\
\cline { 2 - 7 } & $B$ & $V B$ & $B$ & $B$ & $M$ & $S$ \\
\hline
\end{tabular}

Tab.2. Rules bases used for the estimation of parameter Qp (Module \#2).

\begin{tabular}{|c|c|}
\hline $\boldsymbol{S} \boldsymbol{V I}$ & $\boldsymbol{Q p}$ \\
\hline$S$ & $S$ \\
\hline$M$ & $M$ \\
\hline$B$ & $B$ \\
\hline
\end{tabular}
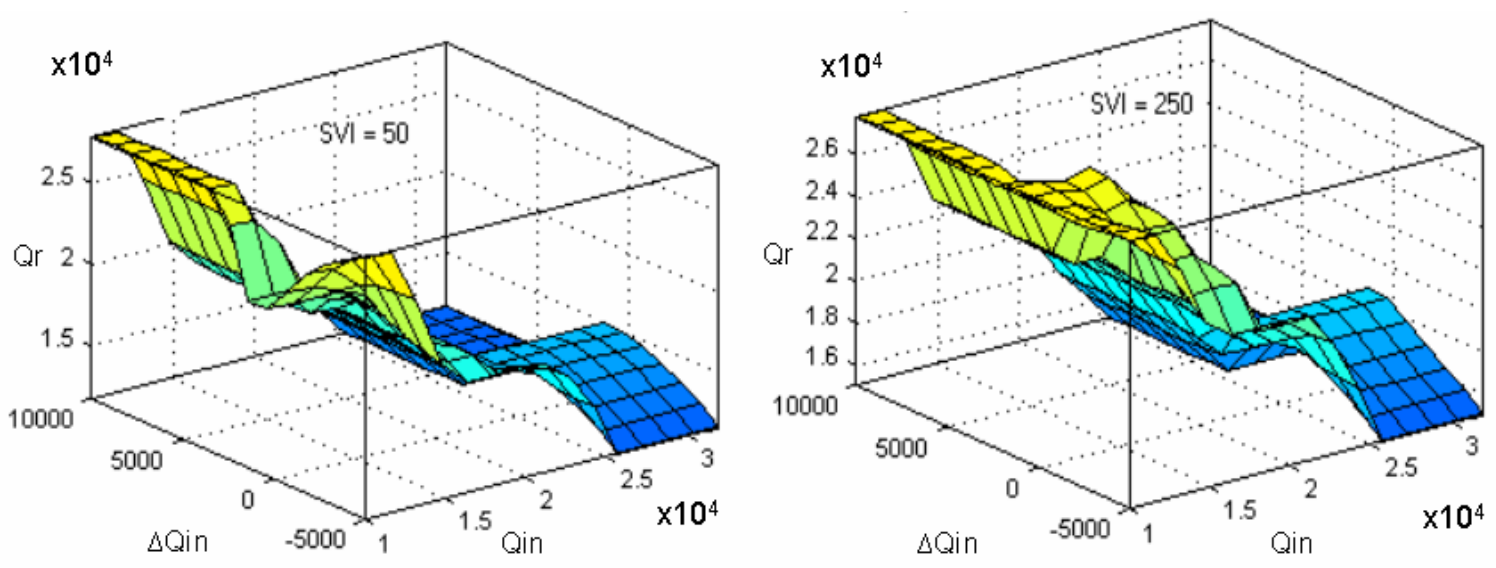

Fig. 6. Variations of Qr according to Qin and $\Delta$ Qin with a SVI fixed at 50 and $250 \mathrm{ml} / \mathrm{g}$.

The definition of the different fuzzy sets and the rules bases has been guided by the exploitation of the controller properties through control surfaces. For example, figure 6 presents the variations of Qr according to Qin and $\Delta$ Qin, with a SVI first fixed at $50 \mathrm{ml} / \mathrm{g}$ and next at 250 $\mathrm{ml} / \mathrm{g}$. The non-linear characterisitic of the controller can be noticed, in opposite to classic regulators like P, PI and PID. The controller characteristics can be adjusted while changing the rules bases or the fuzzy sets in order to obtain a desired and particular behaviour. The used rain scenario includes normal (no rain) and rainy days. The presented structure is able to treat normal days. In order to take into account rainy days (characterized by influent flows higher than $32000 \mathrm{~m}^{3} / \mathrm{d}$ ) and to treat them, a perturbation detection is carried out before the control action. The detection is obtained by comparison with normal days profiles.
To apply the control action, the influent flow Qin is decreased in order to bring back Qin within the range previously defined for the fuzzy sets. The control action is then applied to estimate Qr.

\section{Control results and application to the Cassà-WWTP}

\subsection{Results with the COST 624 simulation benchmark}

This paragraph presents the MESS control results using the COST 624 simulation benchmark. Figure 7 shows the obtained results for the first 20 days (i.e. without rain perturbation), for both increasing and decreasing SVI. The control action is clearly efficient and minimizes MESS fluctuations in the secondary settler. Table 3 and 4 respectively presents the minimum, maximum, mean and standard deviation 
values of the suspended solids concentration for an increasing and a decreasing SVI. In case of rain (Figure 8) the control action also avoids high MESS variations. Globally, the results are satisfactory and confirm the validity of the MESS real time control using the influent flow and the SVI as controller inputs to estimate the sluge recycle and removal flows.
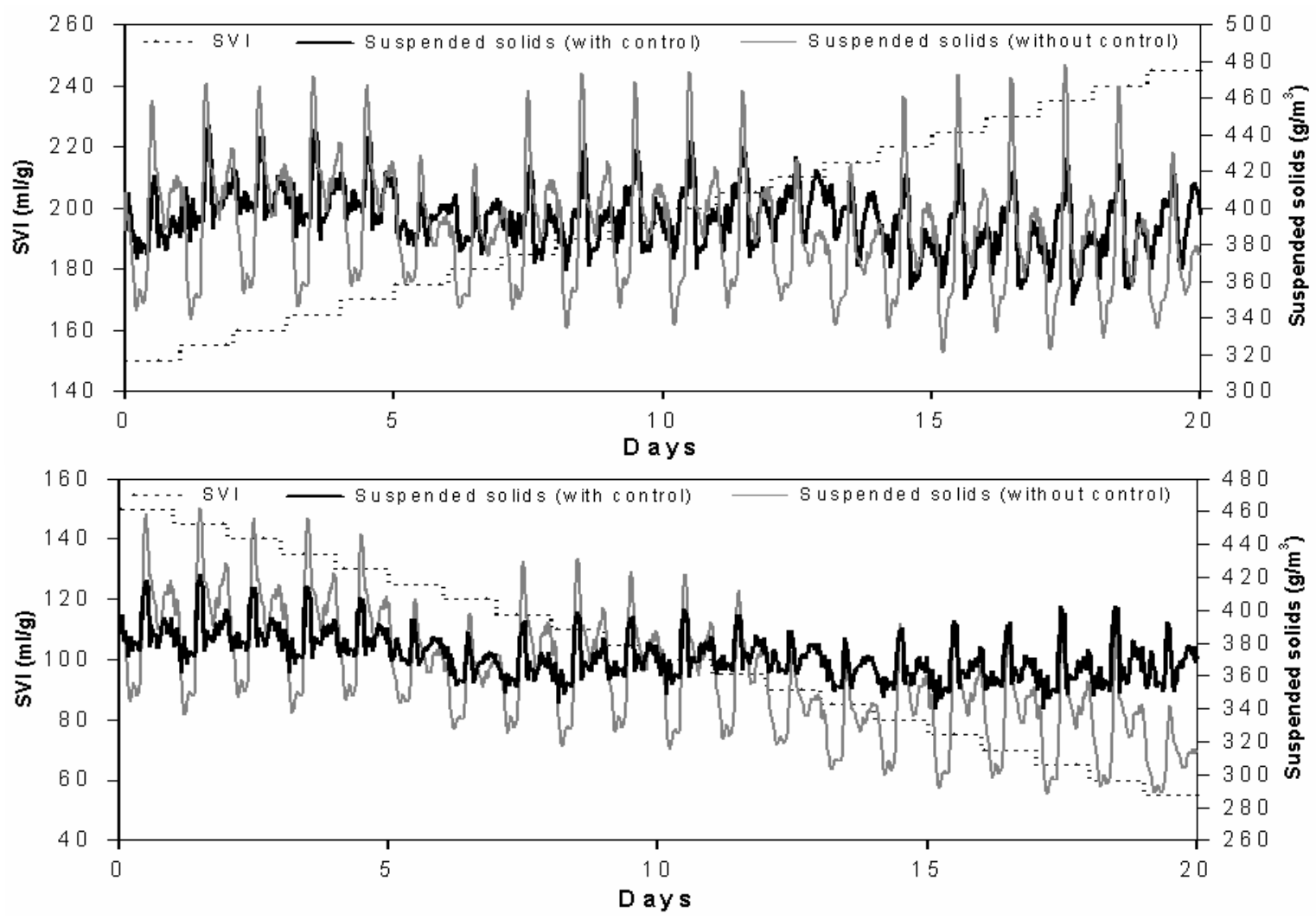

Fig.7. MESS control results for normal days (no rain).

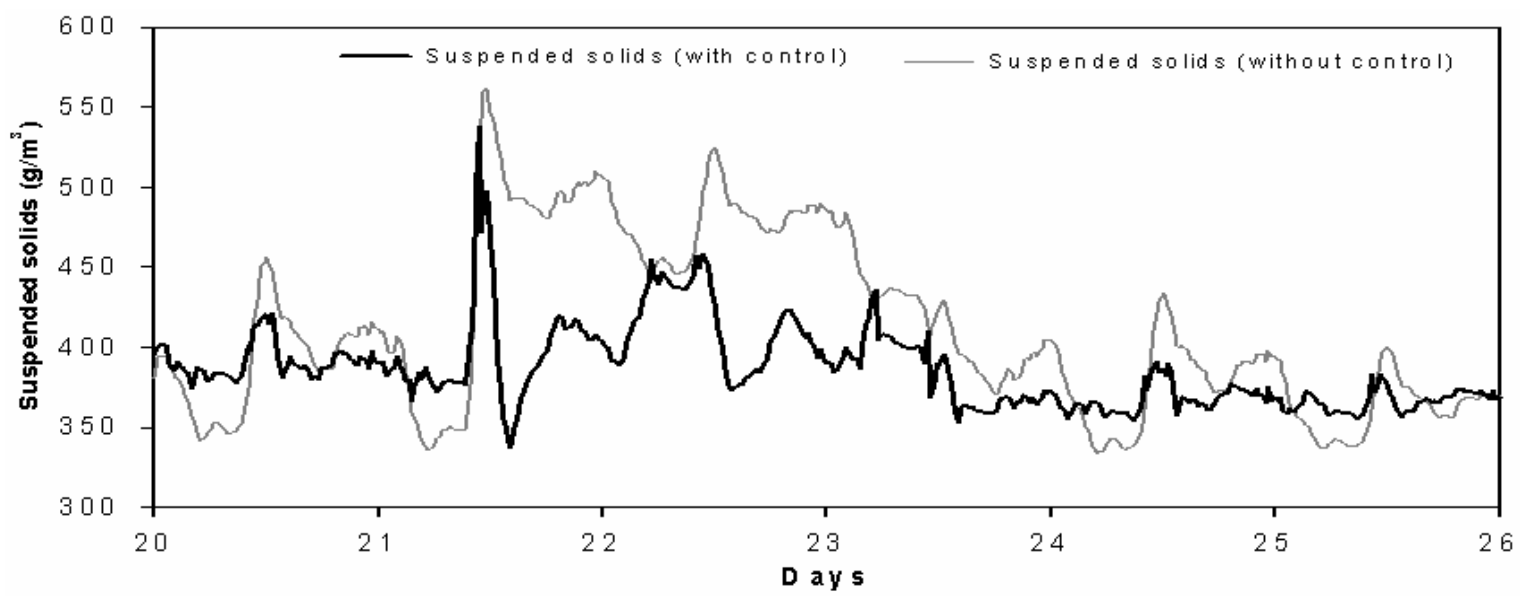

Fig.8. MESS control results for rainy days.

Tab.3. Statistical results (min, mean, max and standard deviation) for an increasing SVI.

\begin{tabular}{|c|c|c|c|c|}
\cline { 2 - 5 } \multicolumn{1}{c|}{} & Min & Mean & Max & Standard deviation \\
\hline $\begin{array}{c}\text { MESS without } \\
\text { control }\end{array}$ & 321,4 & 387,6 & 478,7 & 31,1 \\
\hline MESS with control & 347,6 & 394,6 & 445,4 & 16,7 \\
\hline
\end{tabular}


Tab.4. Statistical results (min, mean, max and standard deviation) for a decreasing SVI.

\begin{tabular}{|c|c|c|c|c|}
\cline { 2 - 5 } \multicolumn{1}{c|}{} & Min & Mean & Max & Standard deviation \\
\hline $\begin{array}{c}\text { MESS without } \\
\text { control }\end{array}$ & 288,4 & 359,1 & 462,6 & 35,9 \\
\hline MESS with control & 340,3 & 372,6 & 421,8 & 13,3 \\
\hline
\end{tabular}

\subsection{Application to the Cassà de la Selva-WWTP}

After developping and testing the controller using the COST simulation benchmark, it was applied to a real wastewater treatment plant. The considered process is carried out at the Cassà-WWTP (Catalonia, Spain) and is based on the classical activated sludge technology. The biological reactor is aerated using three rotors (surface aerators). The influent flow and the SVI for a period of 20 days are presented on figure 9 .

The influent flow daily variations have similar profiles to those obtained with the COST simulation benchmark. An important point is the high variations related to the SVI. This was mainly caused by the variability of the influent quality. Influent flow values at CassàWWTP are ranging between 1252 and $10000 \mathrm{~m}^{3} / \mathrm{d}$.

The developed controller has been applied to the Cassà biological process only adapting the fuzzy sets range. Table 4 presents the new fuzzy sets range adapted to the Cassà process. Let's note that it is the only change needed to obtain satisfactory results.

Table 5 and figure 10 present the results obtained with the direct application of the controller to the Cassà-WWTP. Without control, Qr is fixed at $3195 \mathrm{~m}^{3} / \mathrm{d}$ (mean of Qin in normal situation) and Qp at 105 $\mathrm{m}^{3} / \mathrm{d}$ (default operating value for the plant).

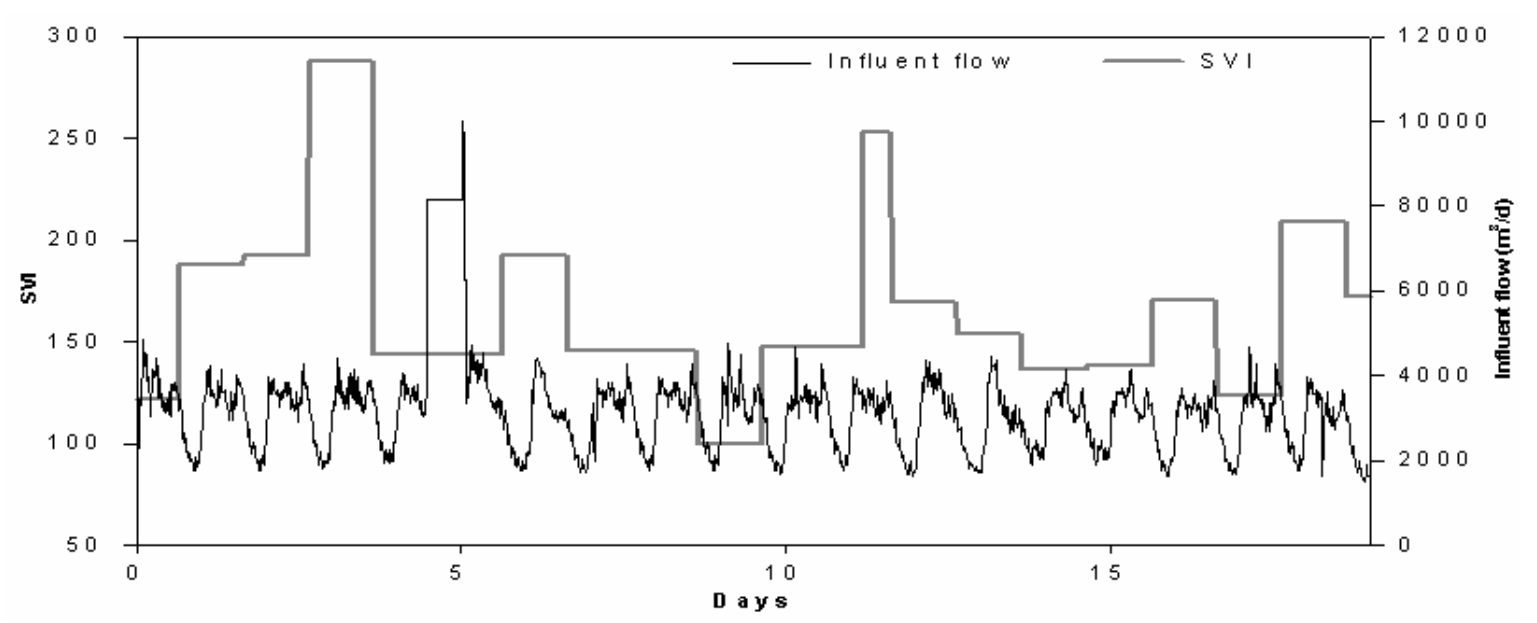

Fig.9. Evolution of parameters Qin and SVI at the Cassà-WWTP.

Tab.4. Fuzzy sets range using COST 624 simulation benchmark and Cassà-WWTP data.

\begin{tabular}{|c|c|c|c|c|c|c|}
\cline { 3 - 7 } \multicolumn{2}{c|}{} & Qin & SVI & $\Delta$ Qin & Qr & $\boldsymbol{Q p}$ \\
\hline $\begin{array}{c}\text { COST 624 simulation } \\
\text { benchmark }\end{array}$ & Min & 10000 & 50 & -5000 & 10000 & 180 \\
\cline { 2 - 7 } & Max & 32000 & 250 & 10000 & 32000 & 580 \\
\hline \multirow{2}{*}{ Cassà-WWTP } & Min & 1500 & 100 & -1000 & 1500 & 0 \\
\cline { 2 - 7 } & Max & 5000 & 350 & 2000 & 5000 & 160 \\
\hline
\end{tabular}


Tab.5. Statistical results (min, mean, max and standard deviation) for the Cassà-WWTP.

\begin{tabular}{|c|c|c|c|c|}
\cline { 2 - 5 } \multicolumn{1}{c|}{} & Min & Mean & Max & Standard deviation \\
\hline MESS without control & 88,8 & 222,9 & 502 & 119,3 \\
\hline MESS with control & 74,3 & 175,3 & 378,4 & 63,2 \\
\hline
\end{tabular}

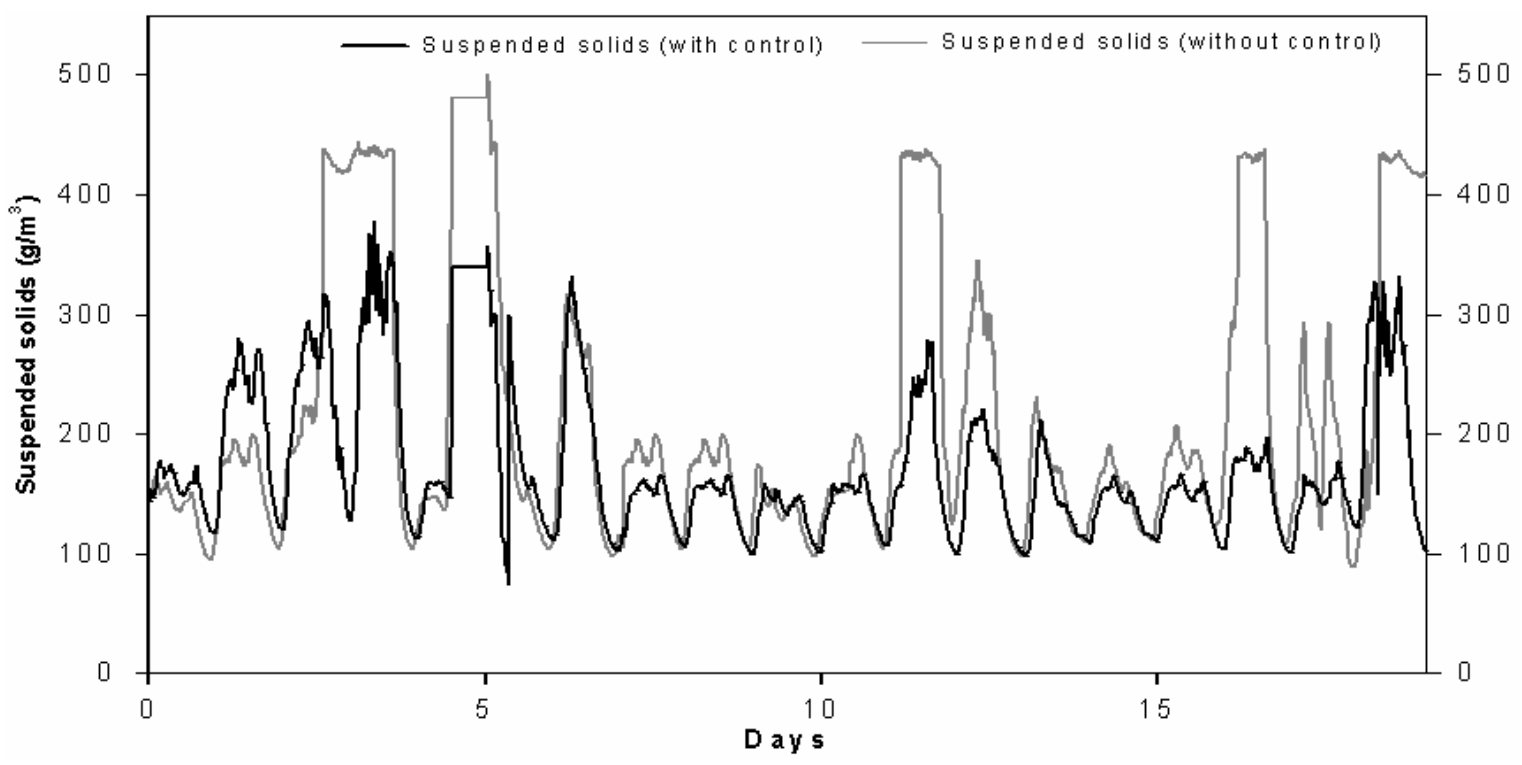

Fig.10. MESS control results for the Cassà-WWTP

Without control, a high variation of the suspended solids concentration in the settler can be observed. Its standard deviation is equal to 119,3 (Tab.5). Globally, the obtainded results are satisfatory. They confirm the validity of the controller structure and that Qin and SVI have an important influence on the suspended solids concentration in a secondary settler (Vanderhasselt \& Vanrolleghem, 2000 ; Diehl \& Jeppsson, 1998).

For high values of SVI, a saturation phenomenon appears. However, it disappears when the controller is applied. The controller presents very good performances for high values of the suspended solids concentration : the maximum decreases from about 500 (without control) to $378,4 \mathrm{~g} / \mathrm{m}^{3}$ (with control) and the standard deviation decreases from 119,3 to 63,2. However, for low values of the suspended solids concentration, the controller presents some insufficiencies. It concerns situations characterized by high values of Qr and will focuse our attention for future works in order to improve the obtained results.

\section{Conclusion}

This paper is focused on the real time control of the suspended solids concentration in a secondary settler. The settling phase efficiency has an important impact on a pollution removal biologic process.

The influent flow and the Sludge Volume Index have been used as controller inputs to estimate the sluge recycle and removal flows. The use of fuzzy logic as control tool made it possible to combine two kinds of knowledge. The process qualitative knowledge obtained from experts and operators working on the plant was first used to define the basic control strategy. This knowledge was completed over simulations, connecting the GPS- $X^{\circledR}$ and MATLAB ${ }^{\circledR}$ softwares. Although the controller structure was developed on simulations, reasoning techniques were used always taking into account real-WWTP working conditions. 
The controlled variable (the suspended solids concentration) is not on-line measurable but the algorithms were developed for an indirect control (without feedback) and an implementation on a real site will not create a problem. The results obtained using the COST 624 simulation benchmark showed the fuzzy controller efficiency for both increasing and decreasing SVI values. Particularly, the rain situation was successfully treated. The application of the controller to the Cassà-WWTP data also allowed an important reduction of suspended solids concentration fluctuations.

The most immediate perspectives are the implementation of the developed fuzzy controller on the Cassà-WWTP for eventual parameters adjustment and validation. A larger scale study on multiagent controllers made of a set of fuzzy controllers, fault detection, diagnostic and supervision will also be considered.

\section{References}

Copp, J. B. (2002). The COST Simulation Benchmark : Description and Simulator Manual, A product of COST Action 624 and COST Action 682, Brussels, Belgium.

Da Motta, M., Pons, M. N. \& Roche, N. (2000). Automated monitoring of activated sludge in a pilot plant using image analysis. Systems analysis and computing in water quality management, $5^{\text {th }}$ International Symposium, Gent, 2.12.6 .

Diehl, S. \& Jeppsson, U. (1998). A model of the settler coupled to the biological reactor. Water Research, Volume 32, Issue 2, 331-342.

Dubois, D., Prade, H. \& Yager, R. (1996). Information engineering and fuzzy logic. Proceedings of the international conference on fuzzy systems, FUZZ IEEE'96.
Ekama, G. A., Barnard, J. L., Gunthert, F. W., Krebs, P., McCorquodale, J. A., Parker, D. S. \& Wahlberg, E. J. (1997). Secondary Settling Tanks : Theory, Modelling, Design and Operation. Scientific and Technical Report, No. 6, International Association on Water Quality, London, UK.

Gomes, J. \& Menawat, A. S. (2000). Precise control of dissolved oxygen in bioreactors, A model-based geometric algorithm. Chemical Engineering Science, 55, 67-78.

Henze, M., Grady, C. P. L. Jr., Gujer, W., Marais, G. V. R. \& Matsuo, T. (1987). Activated Sludge Model No. 1. IAWPRC Scientific and Technical Reports, No. 1, London, UK.

Jenkins, D, Richard, M. G. \& Daigger, G. T. (2003), Manual on the Causes and Control of Activated Sludge Bulking, Foaming and other Solids Separation Problems, $3^{\text {rd }}$ edition. International Water Association, London, UK.

Takacs, I., Patry, G. G. \& Nolasco, D. (1991). A dynamic model of the clarification thickening process. Water Research, 25, 10, 1263-1271.

Vanderhasselt, A. \& Vanrolleghem, P. A. (2000). Estimation of sludge sedimentation parameters from single batch settling curves. Water Research, Volume 34, Issue 2, 395-406.

Vanhooren, H. \& Nguyen, K. (1996). Development of a simulation protocol for evaluation of respirometry-based control strategies, Report University of Gent and University of Ottawa.

Wanner, J. (1994). Activated Sludge Bulking \& Foaming Control. Technomic Publishing Company, Lancaster, PA.

Zadeh, L. (1996). Fuzzy logic computing with words. IEEE Transactions on Fuzzy Systems, 4(2), 103-111. 